\title{
Karjalankieliset verkkosivut virtuaalisena kielimaisemana
}

\author{
ILIA MOSHNIKOV \\ Itä-Suomen yliopisto
}

Tiivistelmä. Fyysisen kielimaiseman tavoin verkkoon ja digitaalisiin ympäristöihin kehittyy virtuaalinen kielimaisema, jossa pienilläkin kielillä on digitalisoitumisen myötä oma sijansa. Tässä artikkelissa tarkastellaan 16:ta verkkosivustoa, joiden rakenne ja sisältö on toteutettu karjalan kielellä. Karjalan kieleltä puuttuu lähes kokonaan fyysinen kielimaisema, mutta karjalankieliset verkkosivustot muodostavat virtuaalisen. Artikkelissa tarkastellaan karjalankielisen verkkoympäristön erityispiirteitä ja tutkimusmahdollisuuksia. Aineistoa käsitellään virtuaalisen kielimaisematutkimuksen ja monikielisyyden tutkimuksen näkökulmasta.

Artikkelissa selvitetään, mitä karjalan kielen varieteettia kyseisillä sivustoilla käytetään ja missä yhteydessä karjalankielisiä sivustoja tehdään. Karjalan kielen käyttö verkkosivujen käyttöliittymänä on hyvin kirjavaa. Karjalankielisen käyttöliittymän kielimuotona on yleensä yksi karjalan murteista, koska yhtenäistä karjalan kirjakieltä ei ole. Toiset sivustot on toteutettu yhdellä murteella, toiset jopa kahdella. Käyttäjälle saattaa jäädä epäselväksi, minkä takia sivustojen kielimuotojen välissä on eroavaisuuksia, vaikka kielivalikossa ilmoitettu kieli on karjala. Aineistoon nojaten myös pohditaan, miten voitaisiin lisätä karjalan kielen näkyvyyttä verkossa ja tukea tällä tavoin kielen elvytystä.

Avainsanat: elvyttäminen; uhanalainen kieli; virtuaalinen kielimaisema; internet; verkkosivu; karjala 
Terveh tulgua Ruočin, Suomen da Venian karjalazet omal kielel kirjuttamah omah virtualizeh Karjalah (http://opastajat.net/forum/)

\section{Johdanto}

Tarkastelen tässä artikkelissa karjalankielisiä verkkosivustoja virtuaalisen kielimaiseman näkökulmasta. Tutkimuskohteena on 16 verkkosivustoa, joiden rakenne ja sisältö ovat kokonaan karjalaksi tai joissa karjala on yksi monikielisen sivuston kielistä. Karjalankieliset verkkosivustot muodostavat virtuaalisen kielimaiseman, jonka fyysinen vastine karjalan kieleltä puuttuu lähes kokonaan reaalielämässä. Verkkosivujen laatiminen karjalan kielellä on suhteellisen yksinkertaista ja nopeaa, kun taas fyysisen kielimaiseman rakentaminen riippuu monesta tekijästä, muun muassa kielen virallisesta asemasta ja asenteista kieltä kohtaan. Artikkelissa esittelen niitä erikoispiirteitä, joita ilmenee uhanalaisen karjalan kielen käyttämisessä verkkoympäristössä.

Digitalisoitumisen myötä pienemmätkin vähemmistökielet ovat saaneet mahdollisuuden elää ja kehittyä verkossa. Vaikka internetin valtakieli on englanti, myös pienten kielten käyttäminen kuuluu internetin arkeen. Käyttäjät kirjoittavat blogeja ja twiittaavat äidinkielellään, selailevat Facebook-profiileja haluamallaan kielellä, pelaavat, kirjoittavat ja kommentoivat päivityksiä eri kielillä. (Soria ym. 2013: 73.) Uhanalaisten kielten kannalta on erityisen tärkeä laajentaa kielen käyttöaloja eli domeeneja. Teknologia mahdollistaa tehokkaamman kielten dokumentoinnin, verkkosanakirjojen ja muiden työkalujen kehittämisen. Internetin ansiosta pienten kielten puhujat pystyvät verkostoitumaan ja tukemaan toisiaan sekä julkaisemaan ilman suuria kustannuksia materiaaleja eri kielillä ja eri aiheista. Juuri ilmaisen julkaisufoorumin ja saavutettavuuden ansiosta internetin merkitys korostuu vähemmistökielen elvytyksessä. Internet ja teknologian käyttäminen on välttämätön osa kielen revitalisaatiota. (Grenoble \& Whaley 2006: 191; Cunliffe 2007: 136; Halonen 2015: 128.) 
Virtuaalisella kielimaisemalla tarkoitetaan digitaalisessa muodossa kehittyvää kielimaisemaa, esimerkiksi verkkosivustoja tai tietokonepelin virtuaalisia ympäristöjä (tarkemmin Ivkovic \& Lotherington 2009; Halonen 2015: 127-128). Sosiolingvistiikkaan kuuluva perinteinen kielimaisematutkimus käsittelee kirjoitetun kielen näkyvyyttä erilaisissa julkisissa ympäristöissä, esimerkiksi kielen näkyvyyttä kaupungin kylteissä ja muissa artefakteissa (Landry \& Bourhis 1997: 25-26). Viimeaikaisessa kielimaisematutkimuksessa korostuu etnografinen ja historiallinen näkökulma. Tutkijat syventyvät visuaalisen ja kvantitatiivisen tutkimuksen rinnalla yhä enemmän syy-seuraus-suhteeseen ja pyrkivät lähestymään kielimaisemaa etnografisesti ja kompleksisesti eli kokemalla ja eläytymällä kieliympäristöön (tarkemmin esim. Blommaert 2013). Monikielistä kielimaisemaa on tutkittu myös käännöstieteen näkökulmasta (Koskinen 2013a, 2013b). Tutkimuksessani sivuan vähemmistökielten tutkimusta ja sosiolingvistiikkaa, ja lisäksi tarkastelen aineistoa käännöstieteen ja verkkokielen tutkimuksen näkökulmasta hyödyntäen Reh’n (2004) monikielistämisstrategioita. Tarkastelen keräämääni aineistoa staattisena virtuaalisena kielimaisemana, analysoin verkkosivustojen rakennetta ja sivustojen keskinäisiä suhteita.

Koska karjalan kielen näkyvyyttä internetissä ei ole aiemmin tutkittu, on tämän artikkelin pyrkimyksenä kartoittaa tilannetta. Artikkelin tavoitteena on vastata seuraaviin kysymyksiin: Minkälaisia karjalankielisiä verkkosivuja on olemassa? Mitä karjalan kielen varieteettia kyseisillä sivustoilla käytetään? Missä asemassa karjalan kieli on suhteessa muihin kieliin? Missä yhteydessä karjalankielisiä sivustoja tehdään, ja kuka on niiden ylläpitäjä? Tarkastelun kohteena ovat sivustot, joista on olemassa täysin karjalankielinen versio. Osittain karjalaa sisältävät sivustot, monikieliset keskustelupalstat sekä yksityinen viestintä (sähköposti, tekstiviestit) jäävät tämän tarkastelun ulkopuolelle. 


\section{Karjalan kielen nykytila ja käyttö verkossa viranomaistasolla}

Karjalan kieli on yksi itämerensuomalaisista kielistä, ja sitä puhutaan pääosin Venäjän Karjalan tasavallassa ja Tverin alueella sekä Suomessa. Karjalan puhujia arvioidaan olevan kaikkiaan noin 55000 (Karjalainen ym. 2013: 10; ks. mуös Всероссийская перепись населения 2010; Ethnologue). Eri arvioiden mukaan Suomessa karjalankielisiä on noin 5000-10 000, ja vielä noin 20000 ihmistä ymmärtää kieltä (Jeskanen 2005: 278; Hämynen 2013: 196; Sarhimaa 2013: 3).

Karjalan kielessä erotetaan venäläisen tutkimusperinteen mukaan kolme päämurretta: varsinaiskarjala, livvinkarjala ja lyydi (Zaikov 2000: 19-29). Varsinaiskarjalaan kuuluvat vienankarjalan, eteläkarjalan ja myös tverinkarjalan murteet. Suomalaisen tutkimusperinteen mukaan karjalan kielessä on kaksi päämurretta: varsinaiskarjala, johon luetaan muun muassa vienalaismurteet ja tverinkarjalaismurteet, ja aunuksenkarjala eli livvinkarjala. Lyydiä pidetään nykyisin tavallisesti omana kielenään eikä karjalan kielen kolmantena päämurteena. Eräät tutkijat pitävät myös varsinaiskarjalaa ja aunuksenkarjalaa eri kielinä. (Torikka 2004; Jeskanen 2005.)

Karjalan kieltä on elvytetty Venäjän puolella ainakin 1980-luvun loppupuolelta: kieltä alettiin opettaa kouluissa ja alkoi ilmestyä karjalankielistä kirjallisuutta. Vuonna 1990 perustettiin “Oma Mua” -lehti ja 1999-2014 julkaistiin myös "Vienan Karjala” -lehteä. Karjalan tasavallassa esitetään karjalankielisiä tv- ja radio-ohjelmia. 1990-luvun alkupuolella perustettiin karjalan kielen terminologinen komissio. Petroskoin yliopistossa on voinut opiskella livvinkarjalaa ja vienankarjalaa. Karjalan tasavalta on kuitenkin Venäjän Federaation suomalais-ugrilaisista tasavalloista ainoa, jonka virallisena kielenä toimii ainoastaan venäjä. Venäjän Karjalassa karjalan, vepsän ja suomen kieltä tuetaan kielilailla, joka astui voimaan vuonna 2004. Elvytystyöstä huolimatta karjalan puhujien määrä supistuu vuosi vuodelta. (Austin 2009: 61, 63-66; Karjalainen ym. 2013: 5, 11, 59, 90.) 
Karjalan tasavallan virallisilla sivuilla (http://gov.karelia.ru/) on kolme erilaista kieliversiota - venäjäksi, suomeksi ja englanniksi - muttei karjalaksi. Esimerkiksi Komin tasavallan vastaavat sivut (http://rkomi. ru/) ovat venäjäksi, komiksi ja englanniksi. Komin tasavallan virallisia kieliä ovat komi ja venäjä. Karjalan tasavallan kolmella kansallisella piirillä, Aunuksen, Prääsän ja Kalevalan piireillä, ei ole karjalankielisiä verkkosivuja. Prääsän piirin sivuilla vain päivämäärä ja viikonpäivä on ilmoitettu karjalaksi (kuva 1). Myös piirin hymni on julkaistu venäjän lisäksi karjalan kielellä.
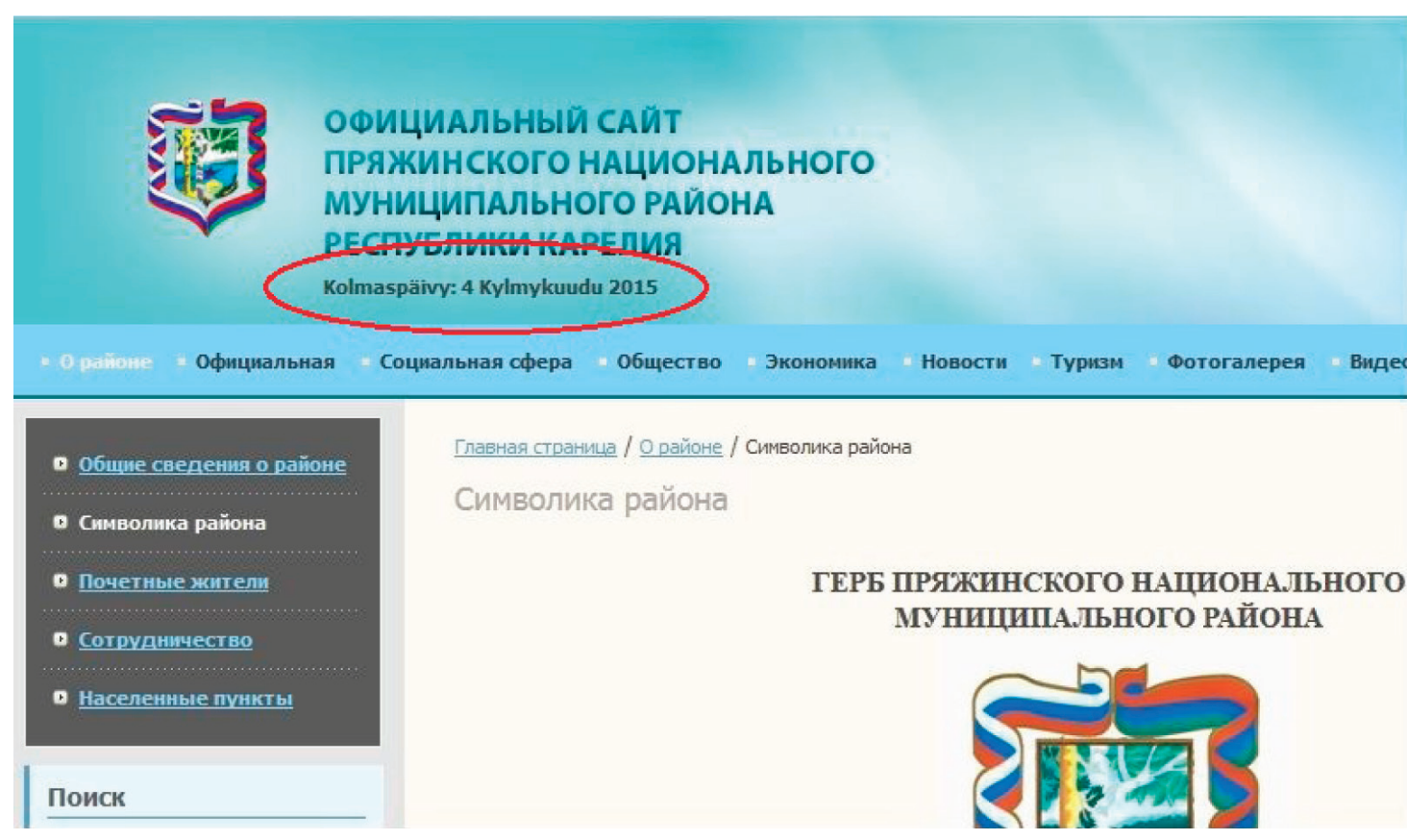

Главная страница / О районе / Символика района

Символика района

Kuva 1. Prääsän kansallisen piirin verkkosivut (http://pryazha.karelia.info/)

Suomessa aktiivinen karjalan elvytys alkoi hieman myöhemmin, 1990luvun loppupuolella vapaan sivistystyön muodossa kansalaisopistoissa. Vuonna 1995 perustettu Karjalan Kielen Seura on aktiivisimpia toimijoita, ja seuran toiminnan päätavoitteena on edistää karjalan kielen asemaa Suomessa (Lemmetyinen 2015: 42). Suomessa karjalalla on vuodesta 2009 alkaen ei-alueellisen vähemmistökielen status (Sarhimaa 2013: 6). Karjalan kielen julkinen näkyvyys on kuitenkin Suomessa 
heikko, ja monet suomalaiset ja myös karjalankieliset pitävät karjalan kieltä suomen kielen murteena (Kunnas 2014: 19). Vuonna 2009 ItäSuomen yliopistoon perustettiin karjalan kielen professuuri, ja vuonna 2010 aloitettiin karjalan kielen ja kulttuurin yliopisto-opetus. Vuodesta 2011 lähtien Suomen asukkaat ovat voineet merkitä karjalan kielen äidinkielekseen Suomen väestörekisteriin. (Munne 2013: 396; Kunnas 2014: 19.) Helmikuussa 2015 Yle aloitti yhteistyössä Karjalan Kielen Seuran ja Itä-Suomen yliopiston kanssa karjalankielisten uutisten tuottamisen.

\section{Kielimaisema, verkkoympäristö ja monikielisyys}

\subsection{Kielimaisematutkimuksesta}

Perinteisesti ajatellaan, että kielimaisema muodostuu julkisen ja yksityisen sektorin erilaisista kylteistä, joista näkyy, mikä tai mitkä kielet saavat näkyvyyttä alueella. Jokainen rajattu alue muodostaa kielimaisemansa, jolla on kaksi päätavoitetta: informatiivisuus ja symbolisuus (Landry \& Bourhis 1997: 25). Kielimaiseman informatiivisuus palvelee alueen asukkaita sekä ilmaisee, mikä tai mitkä kielet ovat käytettävissä tai millä kielillä palvelua voi saada. Tutkijat ovat huomanneet, että julkisen ja yksityisen sektorin kielimaisemalla voi olla suuri merkitys kielen elinvoimaisuuden kannalta. Yksityisen sektorin kielimaisema kuvaa realistista kielitilannetta tarkimmin. Kielimaisemalla on kuitenkin myös vahva symbolinen merkitys kielen elinvoimaisuuden ja käytön näkökulmasta. Kielen käyttö kylteissä symboloi kielen elinvoimaisuutta ja antaa kielelle lisää arvoa. Kielen poissulkeminen kielimaisemasta puolestaan viestii, ettei kielellä ole esimerkiksi käyttöä jokapäiväisessä elämässä. (Landry \& Bourhis 1997: 25-29.) Vähemmistökielelle kielimaiseman symbolisuus on erittäin tärkeää. Viimeaikaisessa kielimaisematutkimuksessa korostuu kielimaiseman dynaamisuus ja muunneltavuus kielellisessä, sosiaalisessa, kulttuurisessa ja poliittisessa kontekstissa. Kielimaiseman kuvauksesta pyritään siirtymään sen kompleksiseen tarkasteluun tilana ja paikkana (engl. space). (Ben-Rafael ym. 2010: xi, xiii; Blommaert 2013: 3, 6-18.) 
Teknologian kehityksen myötä kielimaiseman tutkimus on laajentunut myös virtuaaliseen maailmaan. Virtuaalisen kielimaiseman tutkimuksessa kohteena on digitaalinen maisema, jota voidaan tarkastella fyysisen kielimaiseman tavoin sekä julkisen että yksityisen sektorin osalta. Julkinen virtuaalinen kielimaisema koostuu virallisista verkkoympäristöistä. Yksityisen sektorin kielimaisemaan kuuluvat yksityiset verkkosivustot ja epävirallinen kielenkäyttö esimerkiksi sosiaalisessa mediassa. Virtuaalinen kielimaisema käsittää ihmisten välisen viestinnän internetissä ja myös muissa digitaalisissa ympäristöissä (esimerkiksi tietokonepeleissä ja -ohjelmissa). Samoin kuin fyysisen kielimaiseman tutkimuksessa myös virtuaalista kielimaisemaa tutkittaessa on korostettu kielen yhteiskunnallis-poliittista ja sosiolingvististä asemaa. (Ivkovic \& Lotherington 2009: 17-18; Koskinen 2013b: 5.)

Perinteistä kielimaisemaa on totuttu tarkastelemaan staattisena. Virtuaalinen kielimaisema puolestaan kehittyy nopeasti ja on helposti muunnettavissa, mikä tekee sen tutkimuksesta haasteellista (Halonen 2015: 143). Internet on tällä hetkellä maailman suurin ja monipuolisin sosiaalinen ympäristö, joka yhdistää miljoonia ihmisiä ja joka on murtanut perinteiset käsitykset ihmisten kommunikaatiosta (Blommaert 2016). Fyysinen kielimaisema on yleensä alueellisesti rajattu, mutta virtuaalinen kielimaisema on usein paikatonta. Useammassa tapauksessa kuitenkin voi todeta, että erikieliset verkkosivut palvelevat kielimaiseman tavoin erilaisia käyttäjäryhmiä. Kun on kysymys pienestä vähemmistökielestä, sen ympärille muodostuu tietynlainen kohderyhmä, jota varten sivuja tehdään. (Ivkovic \& Lotherington 2009: 19; Halonen 2015: 143.)

Fyysisen kielimaiseman tavoin virtuaalinen kielimaisema antaa kuvan kielenkäytöstä ja kielen asemasta, myös kielenkäyttäjien omista valinnoista (Ivkovic \& Lotherington 2008: 19). Virtuaalinen kielimaisema linkittyy fyysiseen kielimaisemaan metaforisesti, mitä osoittavat esimerkiksi sellaiset kuvaannolliset ilmaukset kuin chat room tai surffata. Metaforat osoittavat, että käyttäjät siirtävät kokemuksiaan reaalisesta, fyysisestä maailmasta virtuaaliseen. (Mts. 20.) 
Digitalisoinnin myötä virtuaalinen kielimaisema on lyhyessä ajassa noussut fyysisen kielimaiseman rinnalle, koska ihminen käyttää yhä enemmän omaa aikaansa virtuaalisissa ympäristöissä (ks. esimerkiksi Shohamy \& Gorter 2009: 1; Halonen 2015: 142). Internetyhteys on mahdollistanut palvelujen tuottamisen ja ihmisten verkostoitumisen yli rajojen. Uskon, että tästä hyötyvät erityisesti hajanaisesti asuvat vähemmistökansat mutta myös isommat kielet. Virtuaalinen kielimaisema tukee vieraiden kielten opiskelua ja ihmistenvälistä kommunikaatiota.

\subsection{Verkkosivu tutkimuskohteena}

Verkkosivut edustavat ns. web 1.0 -teknologiaa, joka mahdollistaa vain yhdensuuntaisen viestinnän sivujen laatijoilta niiden lukijoille (Salmi 2014: 180; ks. myös Ivkovic \& Lotherington 2008: 20-21). Verkkosivujen kehitys alkoi vuonna 1991, kun Tim Berners-Lee esitti World Wide Web -teknologian (WWW; Ivkovic \& Lotherington 2008: 20), ja verkkosivusto on edelleen yleisin internetissä toimiva yksikkö. Sivustot sisältävät tekstin lisäksi useimmiten myös kuvia, animaatioita, ääntä ja videota. Verkkosivut ja sivustot linkittyvät toisiinsa hyperlinkkien avulla. Sivustojen sisältö on organisaation tai jonkun muun toimijan tuottama ja omistama. Sivuston käyttäjä tai vierailija on useimmiten sisällön tai palvelun kuluttaja. (Cunliffe 2007: 134.)

Teknologian kehitys on mahdollistanut sen, että sivujen käyttäjät pääsevät muokkaamaan niiden sisältöä itse; tälle teknologialle on annettu nimitys web 2.0. Sen käyttäjät eivät ole vain sisällön kuluttajia vaan myös sen tuottajia (tunnettu esimerkki on Wikipedia). Web 2.0:aan liittyvät myös sosiaalinen media, ihmisten verkostoituminen, uudet tavat saada tietoa sekä internetin käyttö muualtakin kuin pöytäkoneelta. (Salmi 2014: 180; Ivkovic \& Lotherington 2008: 21.) 


\subsection{Kielimaiseman monikielisyys}

Tarkastelen tutkimieni verkkosivustojen käyttöliittymiä ja sisältöjä. Monikielisten sivustojen tarkasteluun sovellan Reh'n (2004) kielimaiseman monikielistämisstrategioita, joita Koskinen (2013a) on esitellyt suomeksi. Reh (2004: 8) kirjoittaa seuraavista neljästä strategiasta: toistava (engl. duplicating), osittainen (fragmentary), limittäinen (overlapping) ja täydentävä (complementary). Toistava monikielisyysstrategia on tietynkielisen sisällön toistoa kokonaisuudessaan yhdellä tai useammalla kielellä. Kyseeseen tulee käännös tai toisinto, joka vastaa alkuperäistekstiä. Osittain monikielistetty teksti (eli osittainen käännös) kertoo keskeisimmät asiat useammalla kuin yhdellä kielellä, mutta sen lisäksi tietoa yksinomaan pääkielellä. Limittäisestä monikielisyydestä kyse on silloin, kun useammalla kuin yhdellä kielellä tarjotaan osin sama sisältö, mutta lisäksi kullakin kielellä sellaista ainesta, jota muilla kielillä ei ole. Täydentävällä monikielisyydellä viitataan sellaisiin erikielisiin tekstiaineksiin, jotka eivät sisällä lainkaan samaa tietoa. (Koskinen 2013a: 317-318.)

Vaikka Reh (2004) tarkastelee monikielisiä kirjoitettuja tekstejä, hän ei tutkimuksessaan kirjoita kääntämisestä. Koskisen (2013a) artikkeli Tampereen Hervannan kielimaisemasta tuo puolestaan käännöstieteellisen näkökulman tutkimukseen. Fyysisen kielimaiseman tavoin virtuaalisessa kielimaisemassa ei aina ole selvää, mikä teksteistä on käännös ja mikä alkuteksti. Sekä Reh että Koskinen tarkastelevat monikielistä kielimaisemaa, jolloin tutkimuskohteena ovat lähinnä monikieliset mainokset, kyltit ja ilmoitukset. Omassa tutkimuksessani karjalan kieltä sisältävistä verkkosivustoista ja niiden eri kieliversioista tarkastelen sen sijaan kokonaisten verkkosivustojen käyttöliittymiä ja sisältöjä, jotka on toteutettu eri kielillä. Aineistossani on kolme yksikielistä livvinkarjalaista sivustoa (ks. taulukkoa 1 luvussa 4), joten niiden yhteydessä ei voi puhua monikielistämisstrategioista. "Oma Mua" -lehden sivut on tehty karjalan kielen kahdella murteella, joten käytännössä nekin ovat yksikieliset, mutta vertaan kuitenkin livvin- ja vienankarjalaista versiota. 


\section{Tutkimusaineistona karjalankieliset verkkosivustot}

Karjalan kieltä käytetään verkossa ainakin kolmella eri tavalla. Ensinnäkin on verkkosivustoja, jotka on toteutettu käyttöliittymää myöten kokonaan karjalaksi. Toiseksi karjalaa käytetään keskustelupalstojen kielenä. Kolmas ulottuvuus on karjalan kielen käyttö henkilökohtaisessa viestinnässä kuten tekstiviesteissä, pikaviesteissä ja sähköposteissa. Tässä artikkelissa keskityn karjalankielisten verkkosivustojen tarkasteluun.

Analyysin kohteena ovat sellaiset yksi- tai monikieliset sivustot, joissa vähintään yksi kieliversioista on toteutettu täysin karjalan kielellä (ks. esim. kuvaa 2). Aineiston rajaaminen täysin karjalankielisiin sivustoihin perustuu siihen, että kyseiset sivustot erottuvat sisällöltään ja usein myös tarkoitukseltaan selvästi muista, välillä vain muutaman karjalankielisen sanan sisältävistä sivustoista. Rajaukseen on myös käytännön syy: koko karjalankielisen datan etsiminen internetistä on miltei mahdotonta, ja sitä koko ajan tulee lisää.

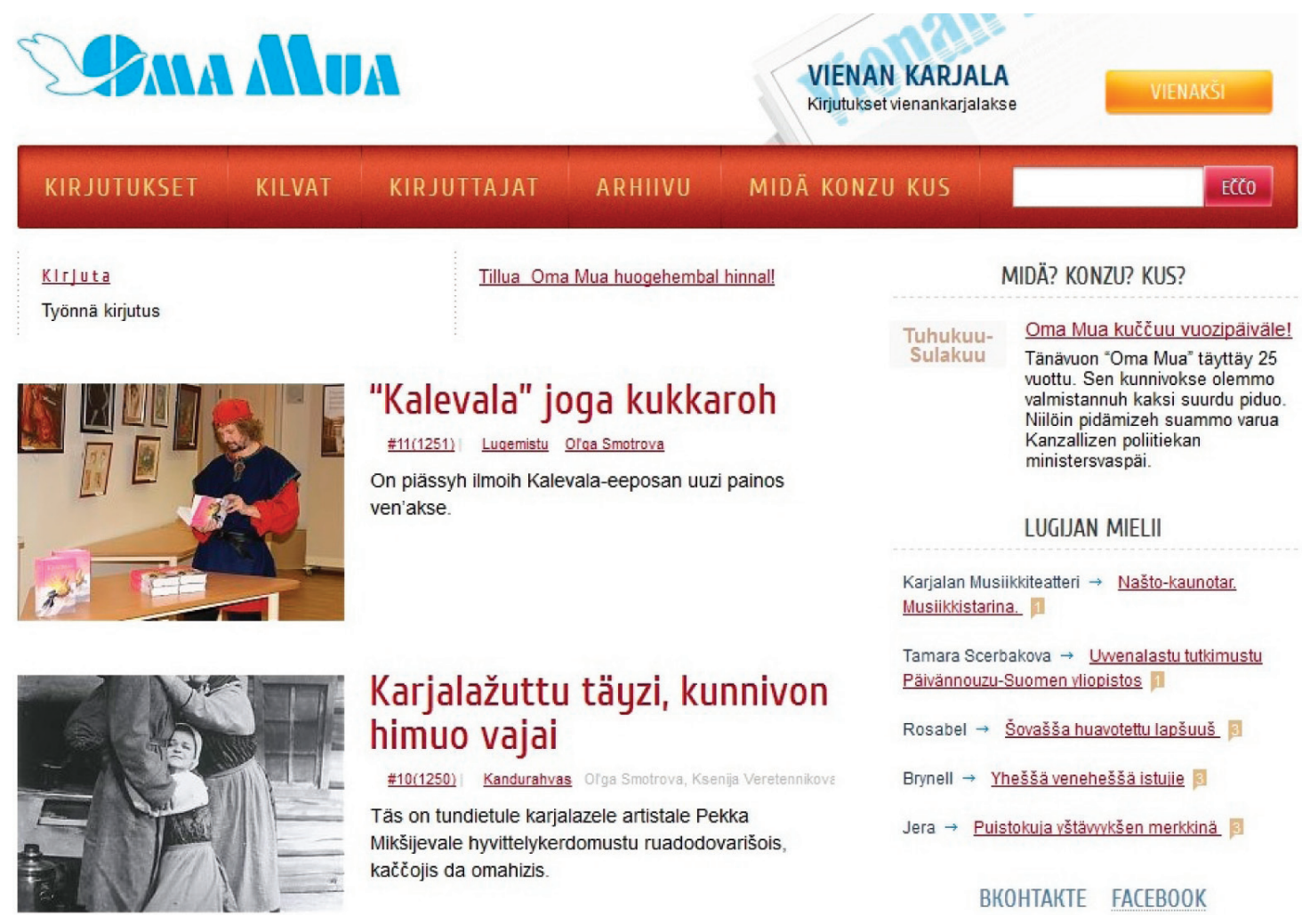

Kuva 2. "Oma Mua”-lehden livvinkarjalankielisen version pääsivu 


\begin{tabular}{|c|c|c|c|c|c|c|c|c|}
\hline 氶 & 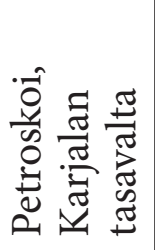 & 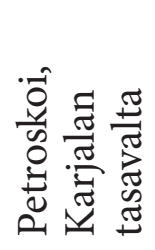 & 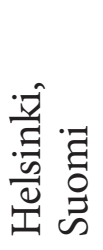 & 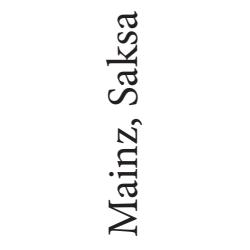 & 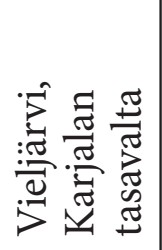 & $\begin{array}{l}\vec{\Xi} \\
\text { Oे } \\
\tilde{\omega}\end{array}$ & $\begin{array}{l}\vec{\Xi} \\
0 \\
\tilde{D}\end{array}$ & 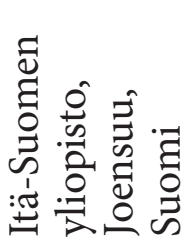 \\
\hline 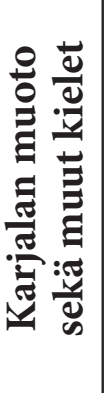 & 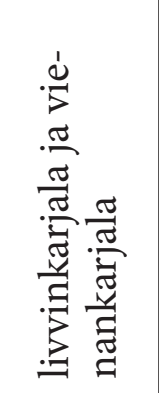 & 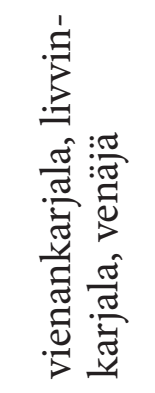 & $\frac{\frac{\pi}{\pi}}{\frac{\pi}{\pi}}$ & 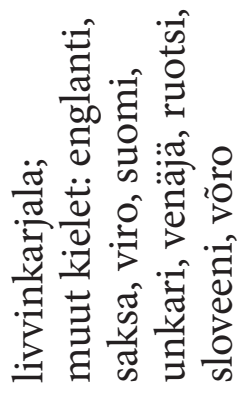 & 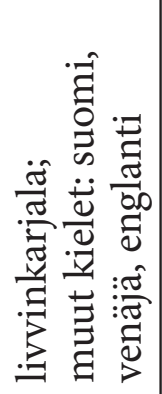 & 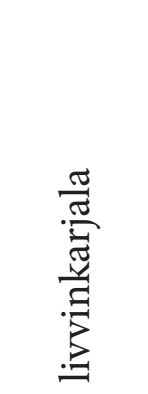 & 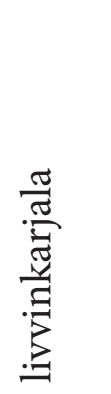 & 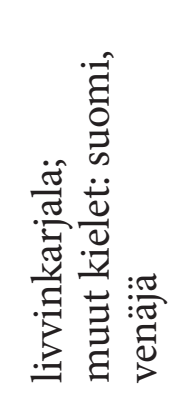 \\
\hline 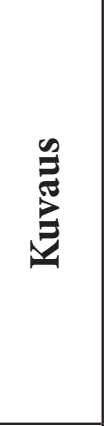 & 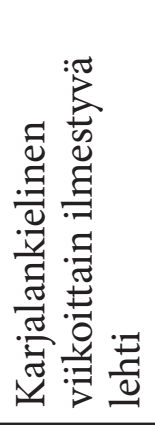 & 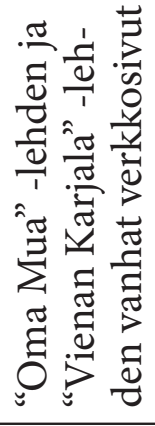 & 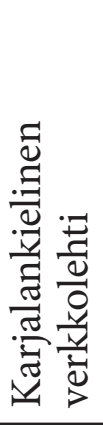 & 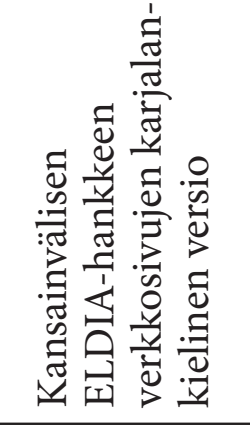 & 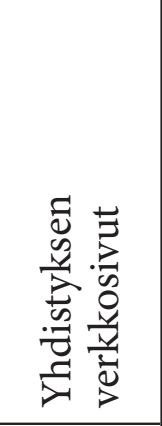 & 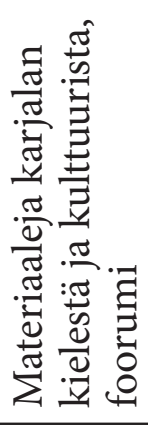 & 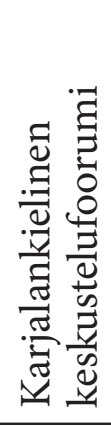 & 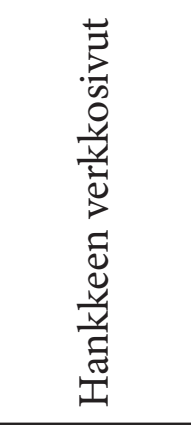 \\
\hline 量 & 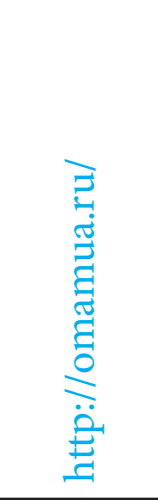 & 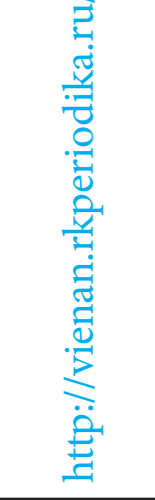 & 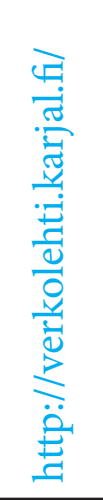 & 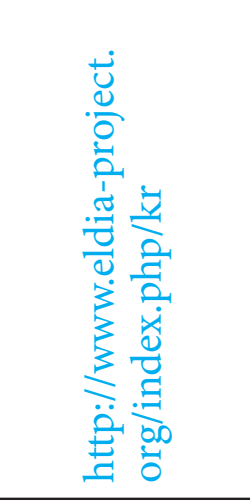 & 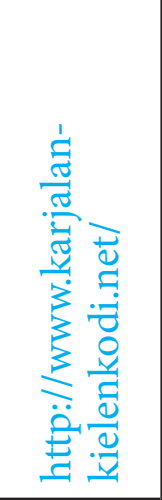 & 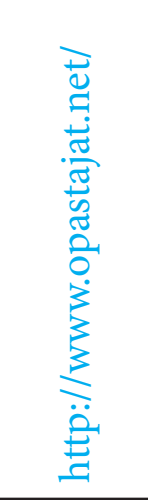 & 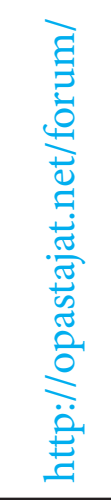 & 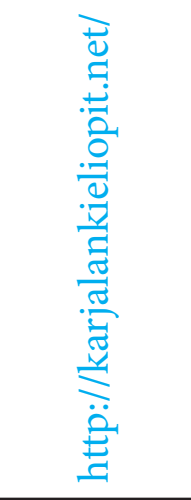 \\
\hline 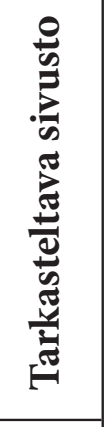 & $\sum_{0}^{\sum_{0}^{\pi}}$ & 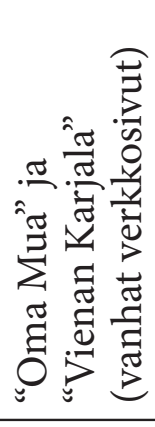 & 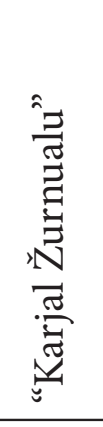 & 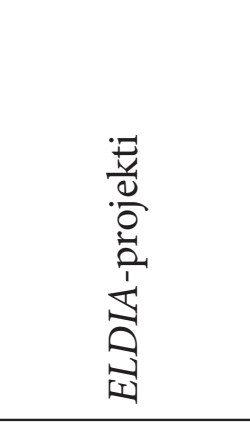 & 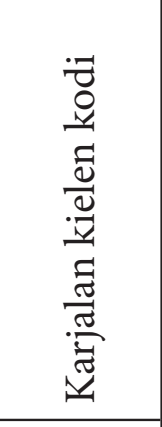 & 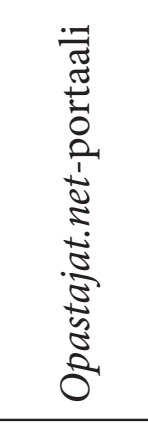 & 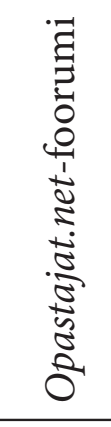 & 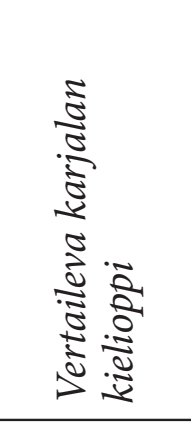 \\
\hline & $\dot{-}$ & $\dot{v}$ & $\dot{\theta}$ & $\dot{\nabla}$ & $\dot{10}$ & $0^{\circ}$ & $\Lambda^{\circ}$ & $\infty$ \\
\hline
\end{tabular}




\begin{tabular}{|c|c|c|c|c|c|c|c|}
\hline $\begin{array}{l}\vec{\Xi} \\
\stackrel{0}{\Rightarrow} \\
\stackrel{5}{\sigma}\end{array}$ & 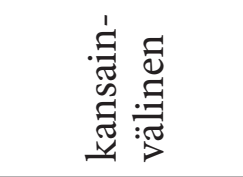 & 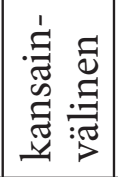 & 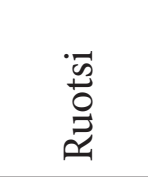 & 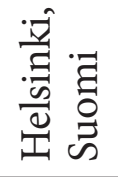 & 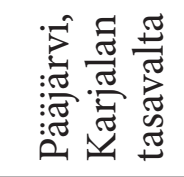 & 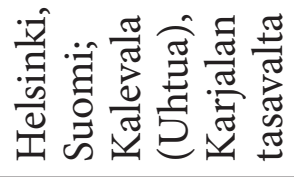 & $\begin{array}{l}\vec{\Xi} \\
\stackrel{0}{0} \\
\stackrel{5}{\infty}\end{array}$ \\
\hline 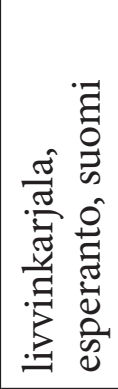 & 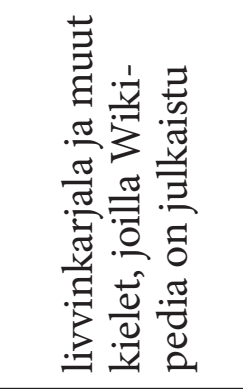 & 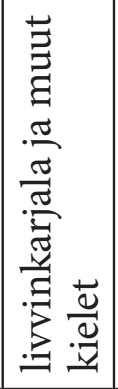 & 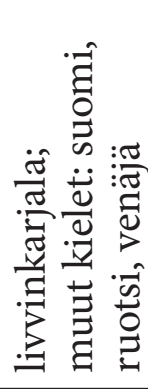 & 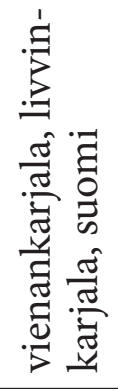 & 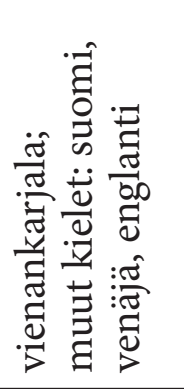 & 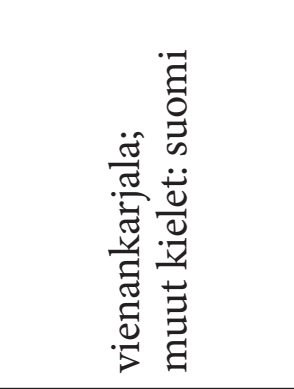 & 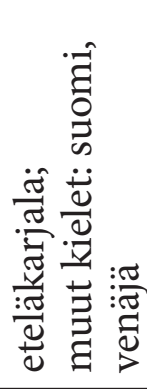 \\
\hline 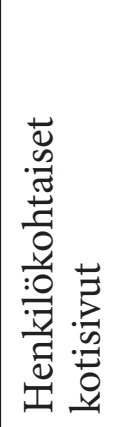 & 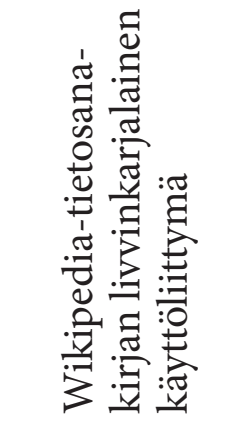 & 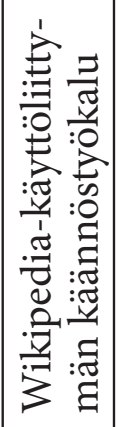 & 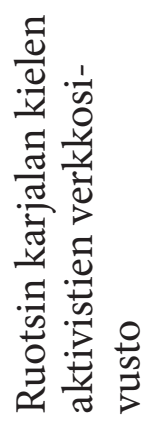 & 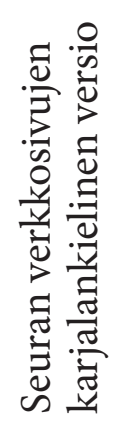 & 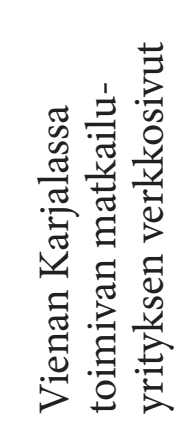 & 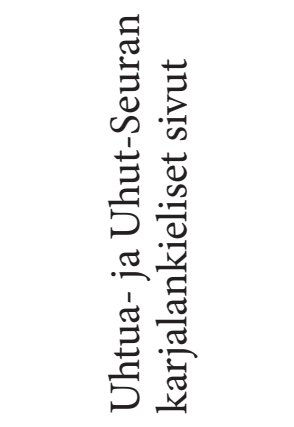 & 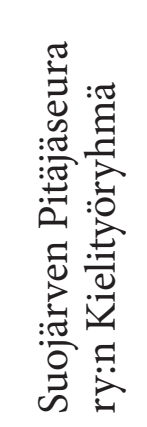 \\
\hline 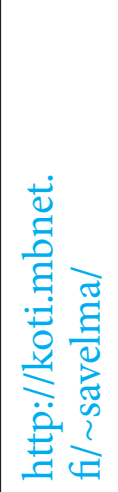 & 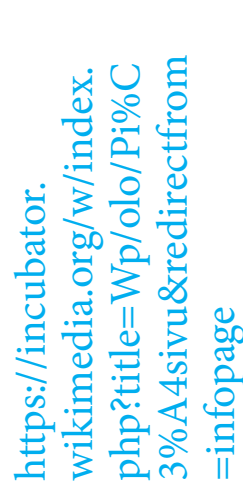 & 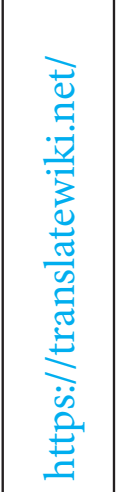 & 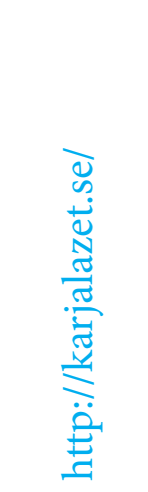 & 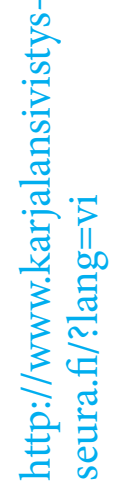 & 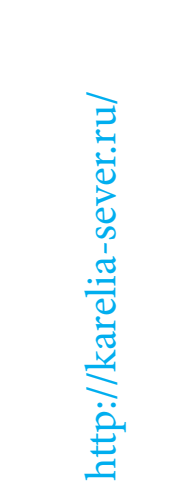 & 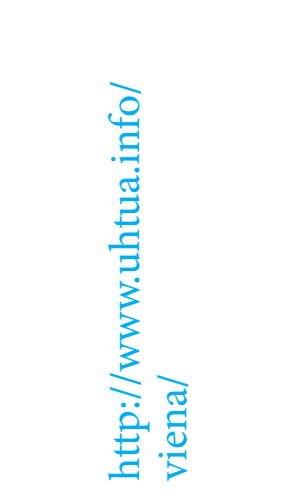 & 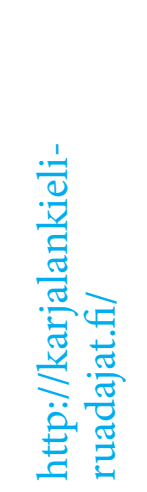 \\
\hline 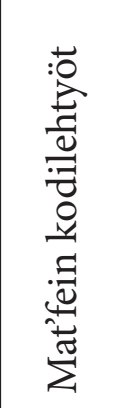 & 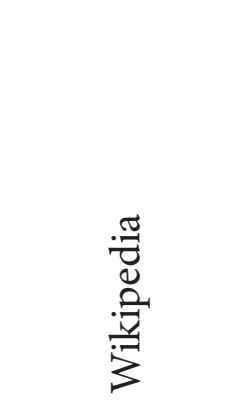 & 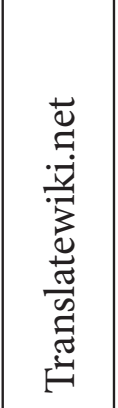 & 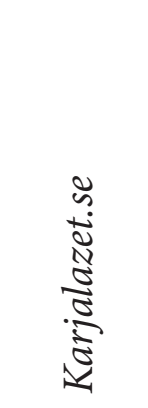 & 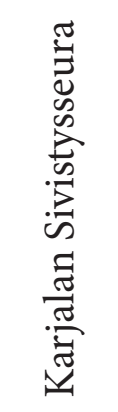 & 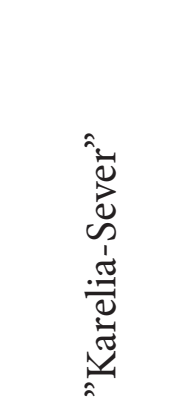 & 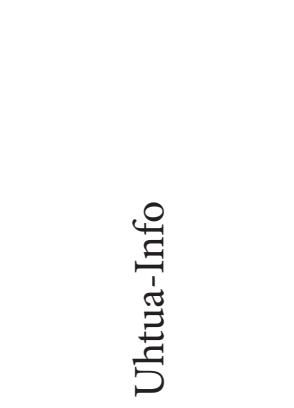 & 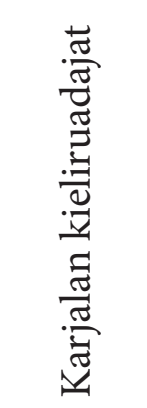 \\
\hline$a^{\circ}$ & $\stackrel{0}{\circ}$ & 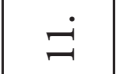 & $\stackrel{\sim}{\sim}$ & $\pi$ & 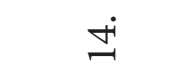 & $\dot{0}$ & $\ddot{0}$ \\
\hline
\end{tabular}


Tässä tutkimuksessa on hyödynnetty Wanca-tietokantaa, jota kehitellään Suomalais-ugrilaiset kielet ja internet -hankkeen (SUKI) yhteydessä Helsingin yliopistossa. Tietokanta sisältää 24 sivustoa (tilanne 30.5.2016), joiden kielikoodi on $\mathrm{krl}$ eli varsinaiskarjala. Livvinkarjalaa (olo) sisältäviä sivustoja on 35. Lyydiä (lud) sisältäviä sivustoja on viisi. Verkkosivustot on kerätty tietokantaan automaattisen ohjelman avulla, ja tästä syystä virheet ovat mahdollisia. Tietokanta listaa sellaiset sivut, jotka sisältävät karjalankielistä materiaalia muutamasta sanasta tai lauseesta kokonaisiin teksteihin.

Tutkimusaineistoksi on valikoitunut 16 karjalankielistä sivustoa. Aineistonkeruun takarajana on 2.12.2015. Sen jälkeen julkaistuja verkkosivuja tai olemassa olevien sivustojen muutoksia ei ole otettu huomioon. Aineisto on kerätty keväällä ja kesällä 2015 Wanca-tietokantaa sekä henkilökohtaisia verkostoja hyödyntäen. Tarkasteltavat sivustot on koottu taulukkoon 1. Taulukossa on lyhyesti esitelty, mitä tahoa sivusto edustaa, mikä karjalan kielen murre on käytössä ja mikä on sivuston (mahdollinen) toimipaikka.

Mainittakoon, että on olemassa sivustoja, jotka lähes täyttävät tutkimusaineistoni rajaamisen kriteerit. Esimerkiksi Ortodoksisten Nuorten Liiton karjalankieliset verkkosivut (http://www.onl.fi/karjala) sisältävät karjalankielisiä materiaaleja, mutta päävalikko on kuitenkin suomenkielinen. Tämäntyyppiset sivustot ovat tulevaisuudessa helposti ja edullisesti muutettavissa kokonaan karjalankielisiksi, eikä niiden merkitystä ole syytä vähätellä, sillä nekin kuuluvat karjalankieliseen virtuaaliseen kielimaisemaan ja lisäävät kielen näkyvyyttä. Tässä tutkimuksessa tarkastellaan kuitenkin kokonaan karjalaksi toteutettuja verkkosivustoja. 


\section{Karjalan kielen käyttö verkkosivustoissa}

Analysoin seuraavaksi, millaisia tarkasteluun valitut karjalankieliset verkkosivut ovat, mikä taho on sivut tehnyt ja julkaissut sekä miten karjalan kieli on niissä näkyvissä. Erityisen kiinnostavaa on se, mikä karjalan kielen murteista on käytössä. Toinen mielenkiintoinen kysymys on se, onko karjalan kieli sivuston pääkieli ja jos ei, vastaako karjalankielinen sisältö muiden kieliversioiden sisältöä.

Aineistossa karjalan kielen käyttö on vaihtelevaa. Kymmenellä sivustolla (ks. kuviota 1) on käytetty joko muiden kielten ohella tai yksinomaan livvinkarjalaa, ja kolmella sivustolla varsinaiskarjalaa. Näiden lisäksi kolmella sivustolla on käytetty rinnakkain molempia päämurteita ("Oma Mua" -lehden vanhat ja uudet verkkosivut sekä Karjalan Sivistysseuran sivut). Pelkästään varsinaiskarjalaksi toimivaa verkkosivustoa ei ole löytynyt. Kolmesta varsinaiskarjalaista sivustosta kaksi on toteutettu vienankarjalaksi ja yksi eteläkarjalaksi. Livvinkarjalaksi toteutettujen sivustojen välillä on myös eroja (ks. kuviota 2). Kolme sivustoa toimii vain livviksi eikä millään muulla kielellä (kielivalikkoa ei edes ole). Kolmella sivustolla on livvin lisäksi versio varsinaiskarjalaksi ja seitsemällä on livvin lisäksi muu kieliversio.

@ livvinkarjala varsinaiskarjala molempia käytetty

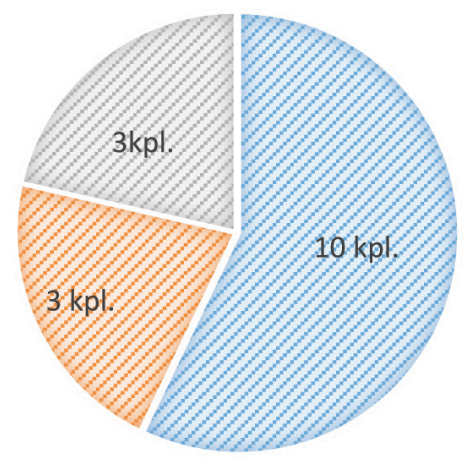

Kuvio 1. Karjalankielisten verkkosivustojen jakautuminen murteittain 
wain livvinkarjala = livvinkarjala+viena livvinkarjala+muu kieli

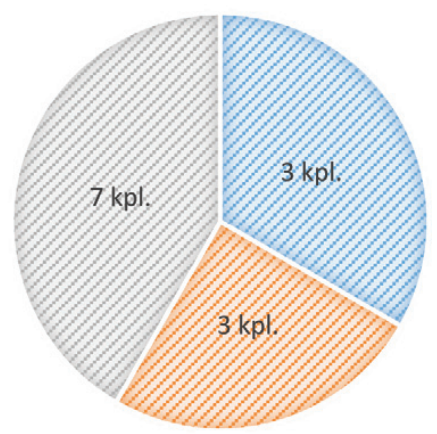

Kuvio 2. Livvinkarjalan käyttö suhteessa muihin kielimuotoihin

Karjalankielinen verkkosivusto tai versio on karjalankielisillä lehdillä (“Oma Mua”, "Karjal Žurnualu”), karjalan kieltä ja kulttuuria tukevilla seuroilla ja yhdistyksillä (Karjalan Sivistysseura, Uhtua-Info, Karjalan kielen kodi, Suojärven Pitäjäseuran ylläpitämä "Karjalan kieliruadajat" -sivusto), tutkimushankkeilla (ELDIA, Vertaileva karjalan kielioppi), yksityisillä yrityksillä tai henkilöillä (“Karelia-Sever”, Mat'fein kodilehyt) ja tietosanakirjoilla (Wikipedia, Translatewiki.net). Opastajat.net-sivusto on portaali, johon on koottu kirjallisuutta karjalan kielellä sekä opetusmateriaaleja karjalan opettamiseksi ja itseopiskeluun. Erillisen linkin kautta pääsee karjalankieliselle foorumille. Vaikka pääsivun ja foorumin URL-osoitteen alkuosa on samanlainen, erottelen tässä artikkelissa portaalin ja foorumin kahdeksi sivustoksi. Foorumi vastaa aineiston kriteerejä, koska sen käyttöliittymä on toteutettu karjalaksi. Tarkastelen tässä liittymän ulkoista rakennetta eli virtuaalista kielimaisemaa enkä ota huomioon keskustelupalstan web 2.0 -sisältöjä.

Tarkastelemalla sivustojen omistajia voi päätellä, että karjalankielisiä verkkosivustoja julkaistaan ja ylläpidetään enemmän Suomessa kuin esimerkiksi Venäjän Karjalassa, vaikka Karjalan tasavallassa karjalan puhujia olisi enemmän. Taulukossa 1 olevista sivustoista ainakin yhdeksän liittyy Suomeen, ja vain kolme on kehitelty täysin Venäjän Karjalassa. Aineiston perusteella voi sanoa, että kielen elinvoimaisuuden näkökulmasta livvinkarjalan kehitys verkkokielenä on edennyt 
pidemmälle varsinaiskarjalaan verrattuna. Livvinkarjalaisia sivustoja on enemmän, ja sivustojen rakenne ja sisältö ovat laajemmat, millä on vaikutusta esimerkiksi sanaston kehitykseen. Joidenkin tutkijoiden mukaan livvinkarjalan murre onkin elinvoimaisempi verrattuna muihin murteisiin (kieliin), ja livvinkarjalaista kirjallisuutta julkaistaan enemmän (ks. esim. Austin 2009: 110; Jeskanen 2005: 277).

Tilanteen 30.5.2016 mukaan hautomossa on tekeillä kolme karjalankielistä Wikipediaa: varsinaiskarjalainen $(k r l)$, livvinkarjalainen (olo) ja lyydiläinen $(l u d)$. Livvinkarjala on lisätty Wikipedian käyttöliittymän kieleksi 1.10.2015, joten se vastaa rajauskriteerejäni. Translatewiki.netkäännösportaalin työkieleksi voi valita livvinkarjalan ilman järjestelmään kirjautumista, mutta liittymän livvinkarjalainen versio on vielä melko puutteellinen.

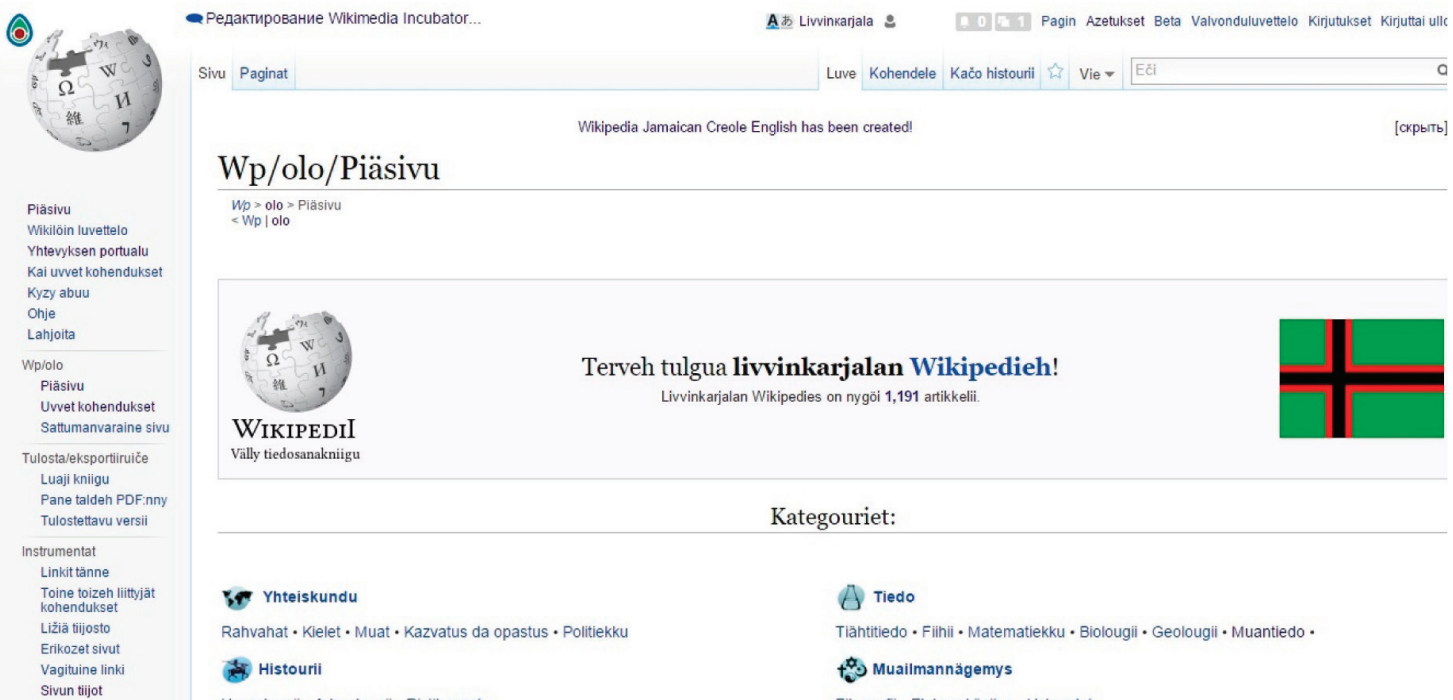

Kuva 3. Livvinkarjalan Wikipedian (hautomo) pääsivun näkymä kirjautuneena käyttäjänä 30.5.2016

Jo tämän pienehkön aineiston perusteella virtuaalinen kielimaisema osoittaa, että karjalan kieltä käytetään internetsivujen rakenteessa vain vähän. Useimmat sivustot liittyvät tavalla tai toisella karjalan kieleen ja kulttuuriin. Wikipedian tekeminen karjalan kielellä on täysin karjalaisten oma aloite. Vapaaehtoistyön tekeminen osoittaa, että joukolle 
aktivisteja on tärkeää edistää karjalan kieltä internetissä. Kielen elinvoimaisuuden kannalta olisi kuitenkin tärkeää, että kieltä käytettäisiin myös verkossa virallisissa yhteyksissä.

\section{Monikielisyysanalyysi}

Tarkastelen seuraavaksi karjalankielisiä sivustoja Reh'n (2004) monikielistämisstrategioiden näkökulmasta. Luvussa 6.1 käsittelen toistavalla ja osittaisella strategialla toteutettuja verkkosivustoja, luvussa 6.2 limittäisellä ja täydentävällä ja luvussa 6.3 täysin karjalankielisiä sivustoja. Jaon perusteena on sivustojen käyttöliittymän rakenne, mutta tarkastelussa vertailen myös sivustojen sisältöjä.

\subsection{Toistava ja osittainen monikielisyys}

Toistavalla monikielistämisstrategialla tarkoitetaan sisällön toistoa kokonaisuudessaan yhdellä tai useammalla kielellä. Enemmistö tutkimistani sivustoista pyrkii käyttöliittymän osalta juuri tähän strategiaan: karjalan kielellä halutaan kertoa samat asiat, mitkä on esitelty muilla kielillä, tai karjalaksi tuotettu sisältö kerrotaan muilla kielillä. Käytännössä on kyse toistavan ja osittaisen monikielistämisstrategian välisestä jatkumosta, jolle sivustot sijoittuvat, ja tästä syystä käsittelen tapauksia samassa luvussa.

Sivustojen erikieliset käyttöliittymät vastaavat pääosin toisiaan, mutta on myös poikkeuksia. Aineistoa leimaa se, että karjalankielinen versio on yleensä suppeampi muunkieliseen versioon verrattuna. Sivustojen sisällön kannalta voi tässä yhteydessä puhua osittaisesta monikielistämisstrategiasta. Esimerkiksi Karjalan Sivistysseuran vienankarjalankielisen version päävalikossa on kuusi kenttää, kun taas suomenkielisessä niitä on kahdeksan ja livvinkielisessä vain kolme. Sivuston vasemmassa laidassa olevat ajankohtaiset uutiset ovat suomenkielisiä. Samoin Uhtua-Infon vienankarjalankielinen sivusto on suomenkielistä sivustoa suppeampi: vaikka päävalikot vastaavat toisiaan, niistä avautuu 
erilaiset määrät sisältöä. Ajankohtaisten uutisten määrä on suomeksi isompi kuin karjalaksi.

"Oma Mua"- ja "Vienan Karjala" -lehtien vanhat verkkosivut ovat toimineet toukokuuhun 2013 asti. Sivut ovat kolmikieliset: käyttöliittymän kieliä ovat livvinkarjala, vienankarjala ja venäjä. Sivuston rakenteessa on selvästi pyritty toistavaan monikielisyyteen, mutta sivustojen sisältö on erilainen, koska kyseessä ovat eri lehdet. Sisältöjen kannalta voi puhua sekä osittaisesta että limittäisestä monikielistämisstrategiasta (ks. tarkemmin lukua 3.3 ja 6.2). Sivuston karjalankielisissä valikoissa on puutteita, eikä sivustoja ole käännetty karjalaksi loppuun asti (ks. kuvaa 4). Moni linkki vie venäjänkieliseen sisältöön (esim. Tilavuskohta). Nämä ovat selkeitä merkkejä siitä, että sivustot oli käännetty venäjästä karjalan eri murteisiin. Tarkistamani venäjänkielinen sisältö on julkaistu, kun taas karjalankieliset osiot saattavat puuttua monestakin kohdasta. Vuodesta 2013 "Oma Mua” -lehti on siirtynyt täysin karjalankielisiin sivuihin.

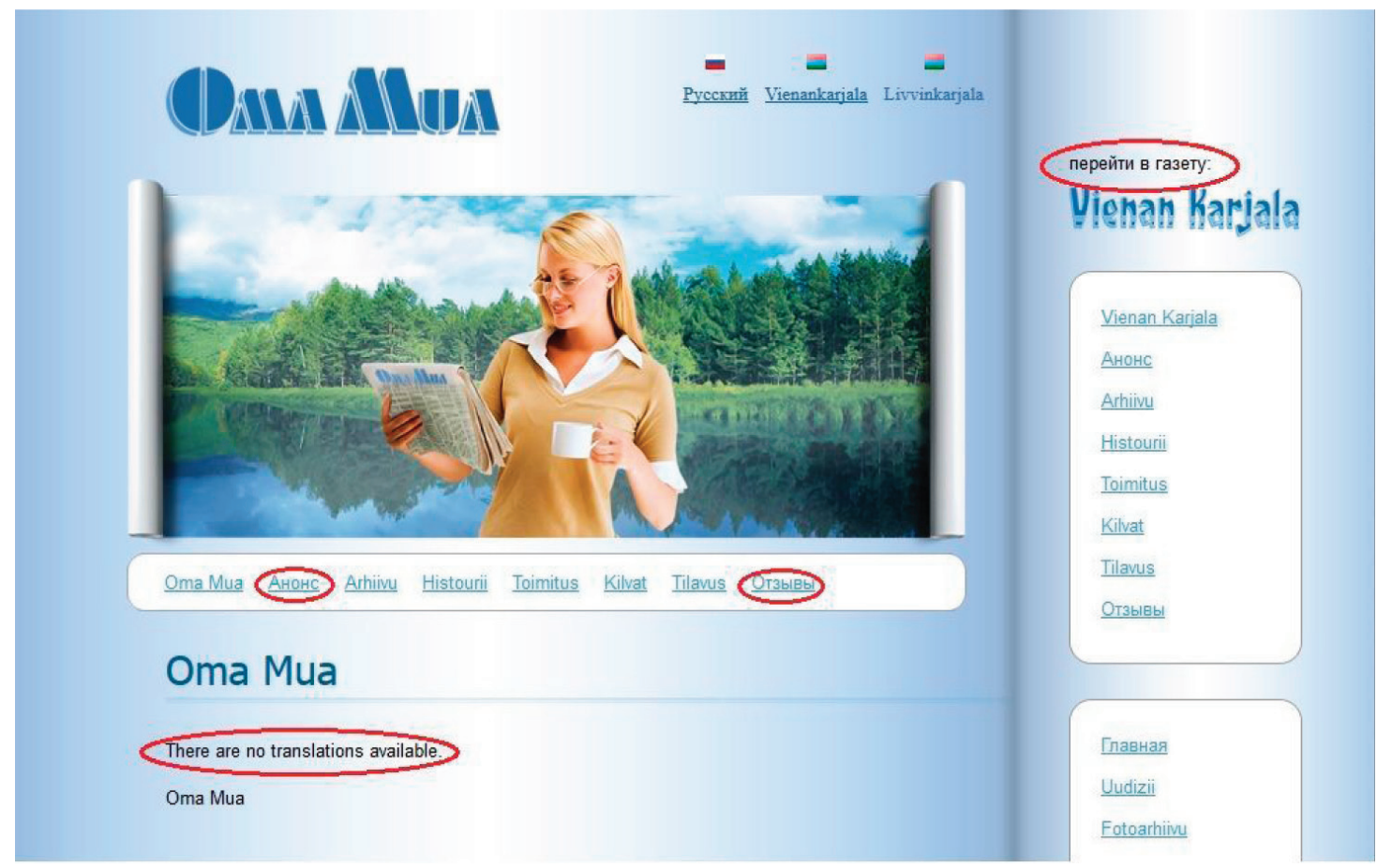

Kuva 4. "Oma Mua" ja "Vienan Karjalan" verkkosivujen vanha versio. Puutteet on ympyröity 
ELDIA-projektin verkkosivustoja voi lukea monella kielellä. Tutkimushankkeessa on pyritty esittelemään tutkimusta ja tutkimustuloksia niillä kielillä, joita on hankkeessa tutkittu. Vasemmassa laidassa kymmenen kielen joukosta voi valita myös karjalan kielen. Tämän lisäksi sivuston oikeassa laidassa on toinen luettelo, johon kuuluu 15 kieltä ja joilla esitellään lyhyesti hanketta (osa näistä on samoja kuin vasemmassa laidassa). Erona on se, että vasemmalla mainituilla kielillä on olemassa koko sivustorakenne (valikkolinkit mukaan lukien), mutta oikealla olevissa linkeissä on saatavilla vain esittely hankkeesta. ELDIA-hankkeen sivusto on esimerkki toistavasta monikielisyydestä: hankkeen keskeiset sisällöt eri kielillä vastaavat toisensa. Erikieliset versiot sisältävät samaa materiaalia. Tarkemmin vertailemalla esimerkiksi englanninkielistä ja karjalankielistä versiota kuitenkin huomaa, että englanniksi kerrotaan enemmän tietoa (esim. kohta ELDIAdata).

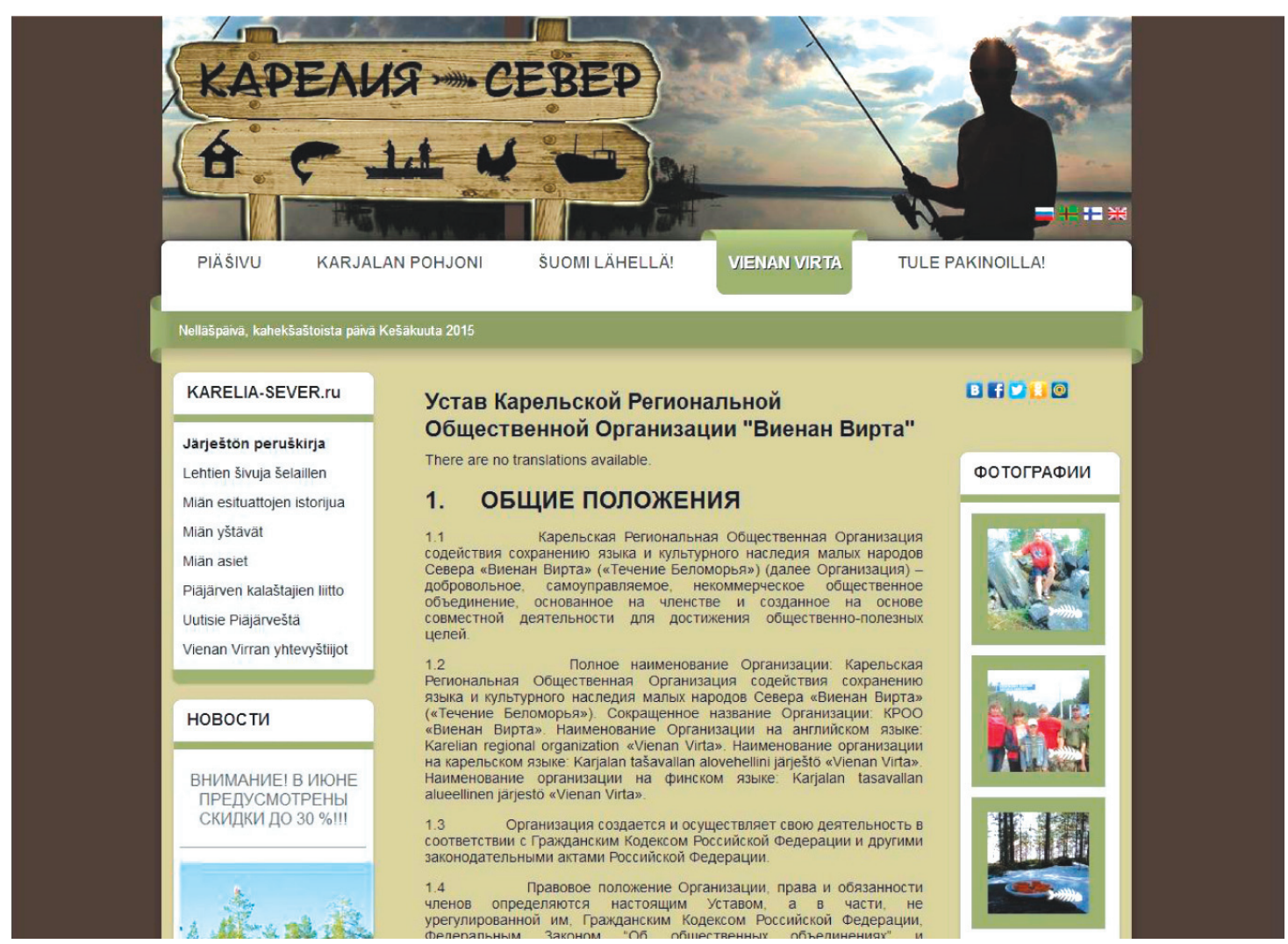

Kuva 5. "Karelia-Sever"-yrityksen karjalankielisen version verkkosivut sisältävät paljon venäjänkielistä tietoa 
"Karelia-Sever"-yrityksen verkkosivut (kuva 5) ovat harvoja aineistoni sivustoja, joiden pääkieli on venäjän kieli. Siinä mielessä sivusto muistuttaa "Oma Mua" -lehden ja "Vienan Karjala" -lehden vanhoja verkkosivuja. "Karelia-Sever" on osittain monikielistetty verkkosivusto (Reh 2004: 8). Sisältö kertoo keskeisimmät asiat useammalla kuin yhdellä kielellä, mutta sen lisäksi osa sisällöstä on yksinomaan pääkielellä eli venäjäksi. Karjalankielistä versiota ympäröivät venäjänkieliset mainokset.

Karjalan kieliruadajat -sivustolla pyritään toistavaan monikielisyyteen, mutta sivuston sisältöjen laatiminen oli aineistonkeruuhetkellä vielä kesken. Erikielisten versioiden päävalikon kohdat vastaavat toisiaan, mutta karjalankielisestä versiosta puuttuvat suomenkielisessä olevat Nettiosoitteita- ja Kielikurssit-kohdat. Sivustolla käytetään karjalan kielen varsinaiskarjalan etelämurretta.

Karjalankielisen Wikipedian ja Translatewiki.net-portaalin sivustot edustavat kansainvälistä kenttää. Reh'n luokittelua on vaikea soveltaa Wikipediaan, sillä Wikipedia yhdistää monesta eri näkökulmasta erilaisia strategioita. Käyttöliittymän osalta pyritään toistavaan monikielistämisstrategiaan, mutta monikielisen käyttöliittymän kääntäminen on jäänyt kesken. Koska sivusto on alun perin yhdysvaltalainen, käyttöliittymän lähdekieli on englanti. Karjalankielisen version kääntämisessä on hyödynnetty englannin lisäksi esimerkiksi suomen, vepsän, viron ja venäjän kieltä. Sisältöjen osalta Wikipediaa voi tarkastella eri strategioiden näkökulmasta: joidenkin artikkeleiden kirjoittamisessa on selvästi hyödynnetty toistavaa strategiaa, toisissa osittaista tai limittäistä, harvemmin täydentävää.

Karjalan kielen kodi (KKK) -järjestön sivuston pääkieli on livvinkarjala, ja kielivalikosta voi siirtyä englantiin, suomeen tai venäjään. Erikieliset versiot ovat keskenään identtisiä mutta karjalaan verrattuna paljon suppeammat. Venäjänkielinen versio on hieman suomen- ja englanninkielistä laajempi. Karjalankielisessä versiossa on valikko ja erilaisia linkkejä, kun taas erikieliset versiot ovat pelkistettyjä, eri kieliin käännettyjä infopaketteja yhdistyksestä, sen toiminnasta ja avustusmahdollisuuksista. KKK:n sivusto on esimerkki osittaisesta monikielisyysstrategiasta: 
keskeisimmät asiat kerrotaan useammalla kielellä, mutta sivusto sisältää myös tietoa, jota annetaan yksinomaan pääkielellä, karjalalla.

\subsection{Limittäinen ja täydentävä monikielisyys}

Kun useammalla kuin yhdellä kielellä tarjotaan osin sama sisältö, mutta lisäksi kullakin kielellä annetaan sellaista ainesta, jota muilla kielillä ei ole, kyseessä on limittäinen monikielisyys. Täydentäväksi monikielistämisstrategiaksi kutsutaan sellaisia erikielisiä tekstiaineksia, jotka eivät sisällä lainkaan samaa tietoa. Aineistoni muutamaa sivustoa voi tarkastella tästä näkökulmasta.

Mat'fein kodilehtyöt -sivuston erikoispiirteenä on se, että suomen ja karjalan lisäksi sivustolla on sisältöjä esperantoksi. Sivuston pääsivun valikon kautta pääsee sivun eri kieliversioihin. Sivustoa on viimeksi päivitetty 24.2.2012. Sivuston karjalan kieli on hyvin erikoista. Kielenkäyttö on vaihtelevaa ja omalaatuista. Sivuston merkityksessä korostuu oma-aloitteisuus ja halu käyttää karjalaa myös verkossa. Sivuston pääsivu on rakennettu toistavan monikielisyyden periaatteella, sillä asioita toistetaan kolmella kielellä tasavertaisesti. Eri kieliversioiden sisällöt kuitenkin eroavat toisistaan huomattavasti, sillä niissä kerrotaan osittain samoja mutta osittain täysin eri asioita.

Karjalan kielen ystävät -yhdistyksen sivustolla (Karjalazet.se) pyritään kertomaan seuran toiminnasta karjalaksi, suomeksi, ruotsiksi ja venäjäksi, ja sivusto sisältää jonkin verran hyödyllisiä linkkejä ja lähteitä. Merkittävää on, että sivuston pääkielenä toimii juuri karjala (livvinkarjala). Blogin kaltainen sivusto toimii uutisten ja linkkien jakajana ja tapahtumien mainostajana. Selailemalla sivustoa huomaa, että erikieliset versiot tarjoavat erilaista tietoa. Aineistoni sivustoista tämä sopii parhaiten täydentävän monikielistämisstrategian määritelmään. 


\subsection{Yksikieliset sivustot karjalan kielellä}

Aineistossani on neljä sivustoa, jotka on julkaistu vain karjalan kielellä. Tähän on laskettu mukaan Vertaileva karjalan kielioppi -hankkeen sivut, jotka toimivat aineistonkeruuhetkellä ainoastaan karjalaksi. Jatkossa kyseinen sivusto täydentyy englannin-, suomen- ja venäjänkielisillä versioilla, sillä juuri nämä kielet voi valita sivuston kielivalikosta. Yhdellä sivustolla ("Oma Mua" -lehti) on kaksi rinnakkaisversiota livvin- ja vienankarjalaksi. Vaikka molempia käytetään "Oma Mua" -lehdessä työkielinä, teknisesti livvinkarjala on asetettu sivuston pääkieleksi, sillä livvinkarjalainen versio löytyy hakukoneista ja avautuu ensimmäisenä. Sisällön näkökulmasta livvin- ja vienankarjalainen versio eivät ole täysin identtisiä: verkkosivuilla julkaistaan eriaiheisia artikkeleita livviksi ja vienaksi. Myös sivuston rakenteessa on pieniä eroja. Reh'n terminologiaa käyttäen voi käyttöliittymän osalta puhua limittäisestä monikielisyydestä (2004: 12): toisen kieliversion sisältö vastaa vain osin toista (etusivun pääpalkista näkyvät murteiden väliset erot; ilmoitukset-kohdassa on käytetty eri ilmauksia: kirjutukset - kirjutukšet, kilvat - kilpailut, kirjuttajat - kirjuttajat, arhiivu - arhiiva, Midä Konzu Kus - ilmotukšet). Kumpikin kieliversio sisältää aineistoja vain yhdellä kielimuodolla (vrt. kuvaa 2 kuvaan 6). Käytännössä livvin- ja vienankarjalainen versiot voisivat toimia itsenäisinä sivustoina.

Muut kolme vain karjalan kielellä julkaistua sivustoa, livvinkarjalaiset "Karjal Žurnualu”, opastajat.net ja opastajat.net-foorumi, ovat yksikielisiä. Karjalankielisiä (yksi- sekä monikielisiä) sivustoja olisi kiinnostavaa tarkastella suomi-karjala-kielikontaktin, interferenssin sekä käännöstieteen näkökulmasta. Tutkimuksissa todetaankin, että vähemmistökielille kääntämistä on käännöstieteen näkökulmasta tutkittu hyvin vähän (Cronin 1995; 1998). Vähemmistökielten kääntämisen tutkimuksessa on käytetty termiä hallittu tai kontrolloitu interferenssi (engl. controlled interference), joka nähdään mahdollisuutena eikä haittana vähemmistökielen elinvoimaisuuden näkökulmasta (Toury 1985: 8; Paulasto ym. 2014). 


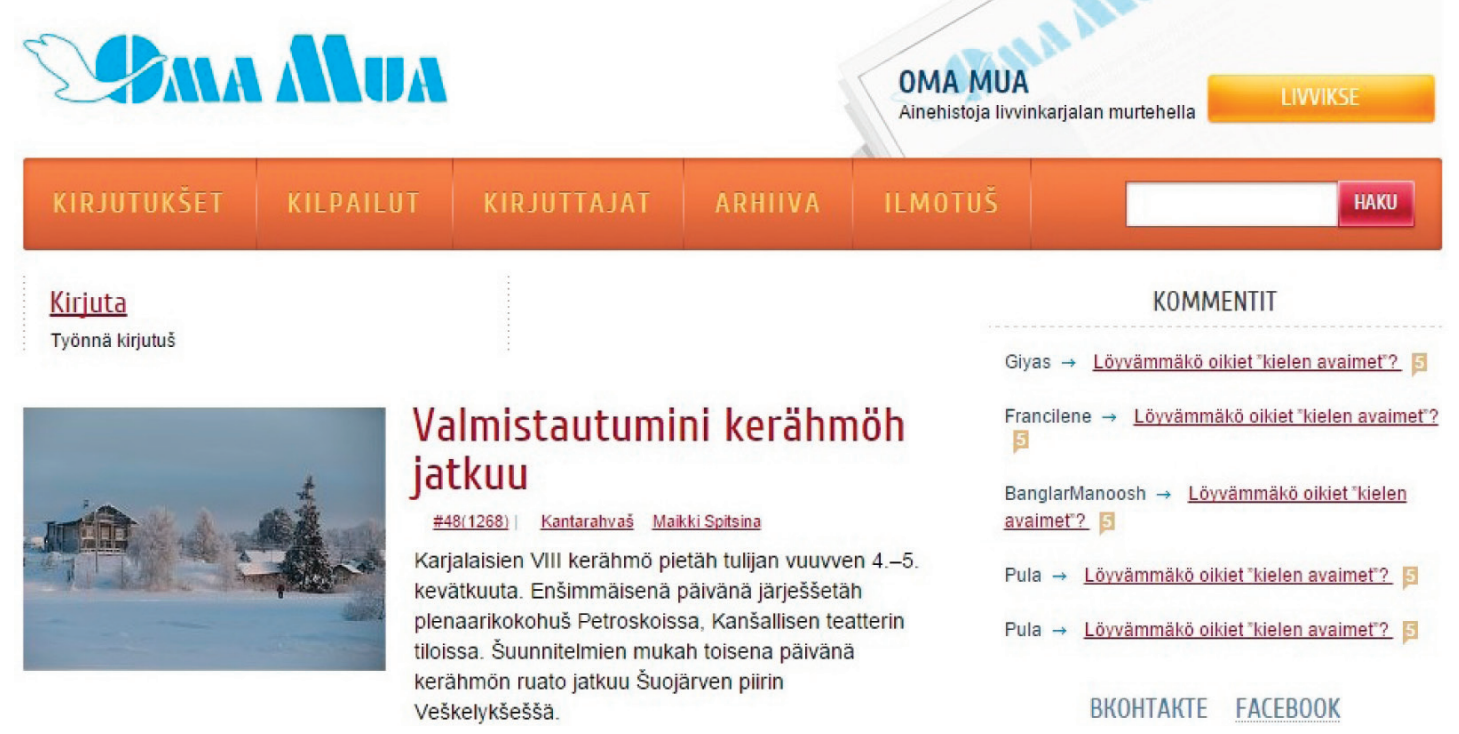

Kuva 6. “Oma Mua”-lehden vienankarjalankielisen version pääsivu

Vähemmistökielet tarvitsevat kipeästi uuden sanaston kehittämistä, ja usein uutta sanastoa luodaan nimenomaan kääntämisen yhteydessä. Karjalaksi käännetään pääosin suomesta ja venäjästä; tämä vaikutus heijastuu esimerkiksi etusivu-sanan variaatiossa piäsivu $\sim$ ezisivu $\sim$ edusivu algusivu. Piäsivu on "Oma Mua" -lehden verkkosivuilta ja viittaa selvästi venäjänkieliseen ilmaukseen главная страница. Kolme muuta varianttia ovat peräisin suomalaisilta karjalankielisiltä sivustoilta; ne ovat käännöslainoja sanoista etusivu tai aloitus-, alkusivu.

\section{Lopuksi}

Karjalankieliset verkkosivustot muodostavat melko kirjavan virtuaalisen kielimaiseman. Karjalan kehittyminen verkossa on tärkeää kielenkäytön ja elvyttämisen kannalta. Internetiin muodostuu virtuaalinen kielimaisema, joka tukee kielen käyttöä, nostaa kielen arvoa ja vaikuttaa kieliidentiteettiin. Monelle karjalan kielen taitoiselle karjalan kielen käyttö verkossa on ainoa mahdollisuus ylläpitää ja kehittää kielitaitoaan.

Suurin osa karjalankielisistä sivustoista on seura- ja vapaaehtoisvoimin kehiteltyjä. Karjalankielisiä versioita verkkosivuistaan ovat myös tehneet tutkimushankkeet, lehdet ja yksityiset henkilöt ja yritykset. 
Yksikään aineistooni kuuluva sivusto ei ole esimerkiksi valtion, kunnan, piirin tai kaupungin tekemä. Virallisella tasolla karjalankielisiä verkkosivuja ei julkaista.

Aineisto osoittaa, että toistavaan monikielisyyteen on hyvin vaikea päästä vähemmistökielen kontekstissa. Isot sisällöt ja sivuston ylläpitäminen vaativat resursseja, mm. kielitaitoisia kääntäjiä. Resurssien puute on vakava ongelma karjalan kielen kentällä (ks. myös Moshnikov, tulossa). Jos karjala on sivuston toinen tai sivukieli, sillä tuotettu sisältö on yleensä suppeampi pääkieleen verrattuna. Yksinomaan karjalaksi toteutetut sivustot toimivat näin tietynlaisena protestina tälle epätasaiselle suhteelle: niissä karjala on nostettu päärooliin sivuston ainoaksi kieleksi. Aineistoni sisältää kuitenkin muutaman monikielisen sivuston, jonka pääkielenä toimii karjalan kieli. Silloin muilla kielillä tuotettu sisältö on suppeampi.

Sivustot on toteutettu karjalan kielen kolmella murteella: varsinaiskarjalan kahdella murteella (vienankarjala ja eteläkarjala) sekä livvinkarjalaksi. Livvinkarjalaisia sivustoja on muihin verrattuna enemmän. Kun eri sivustoilla käytetään erilaista karjalaa, voi karjalan kieltä taitamattomalle jäädä epäselväksi, miksi karjalankielisten sivustojen välillä on isoja eroja. Toiset sivustot erottelevat vienan- tai varsinaiskarjalan livvinkarjalasta (esim. "Oma Mua"), toiset eivät (esim. ELDIA-hankkeen Karjalakse-versio on livvinkarjalaa). Jotkut tahot pyrkivät edistämään karjalaa murteesta riippumatta, toisille karjalaa on vain tietty murre. Taustalla vaikuttavat kieli-ideologiset ja kielipoliittiset kysymykset.

Karjalan kieli tarvitsisi kipeästi käyttödomeenien laajentamista verkkoon, sillä kielen näkyvyys vaikuttaa myös kieliasenteisiin. Karjalan kieltä olisi lisättävä mm. julkisen sektorin verkkosivuille. Monikielisten sivustojen suunnittelussa on otettava huomioon myös karjalan kieli. Kielitaitoisten ammattikääntäjien koulutusta on jatkettava. Digitaalisia tuotteita (erilaisia monikielisiä sovelluksia ja pelejä) on kehiteltävä, sosiaalisen median käyttöliittymiä on käännettävä karjalaksi. Pienetkin karjalan kielen näkyvyyttä lisäävät teot tukevat karjalan kielen elvytystä. 11.10.2016 livvinkarjalan Wikipedia on julkaistu (ks. https://olo. 
wikipedia.org/wiki/Piäsivu). Wikipedia-työ eri karjalan murteilla jatkuu ja artikkeleita tulee koko ajan lisää.

\section{Kiitokset}

Tutkimus on osa Kiännä-hanketta (2015-2018), jonka on rahoittanut Koneen Säätiö. Ks. tarkemmin: http://kianna-hanke.blogspot.fi/p/esittely.html. Haluaisin kiittää prof. Kaisa Koskista, prof. Mikko Laitista, FT Helka Riionheimoa, Olga Karlovaa sekä Kontu-hankkeen työryhmää hyödyllisistä kommenteista. Kiitän myös tekstini kahta anonyymia arvioijaa.

\section{Lähteet}

Austin, Paul 2009. The Karelian Phoenix. Studies in Languages 45. Joensuu: Faculty of Humanities, University of Joensuu.

Ben-Rafael, Eliezer, Elana Shohamy, Monica Barni 2010. Introduction. - Elana Shohamy, Eliezer Ben-Rafael, Monica Barni (Eds.), Linguistic Landscape in the City. Bristol: Multilingual Matters.

Blommaert, Jan 2013. Ethnography, Superdiversity and Linguistic Landscapes: Chronicles of Complexity. Bristol: Multilingual Matters.

Blommaert, Jan 2016. The conservative turn in Linguistic Landscape Studies. http://alternative-democracy-research.org/2016/01/05/the-conservativeturn-in-linguistic-landscape-studies/ (17.5.2016).

Cronin, Michael 1995. Altered states: Translation and minority languages. - TTR: Traduction, Terminologie, Redaction 8 (1), 85-103.

Cronin, Michael 1998. The cracked looking glass of servants. Translation and minority languages in a global age. - The Translator 4 (2), 145-162. http:// dx.doi.org/10.1080/13556509.1998.10799017

Cunliffe, Daniel 2007. Minority languages and the Internet: New threats, new opportunities. - Mike Cormack, Niamh Hourigan (Eds.), Minority Language Media. Concepts, Critiques and Case Studies. Multilingual Matters 138. Clevedon-Buffalo-Toronto.

Ethnologue. Languages of the World. Karelian. https://www.ethnologue.com/language/krl (17.5.2016).

Grenoble, Lenore A., Lindsay J. Whaley 2006. Saving Languages. An Introduction to Language Revitalization. Cambridge: Cambridge University Press.

Halonen, Mia 2015. Social media landscapes: Tracing the uses and function of a hybrid sign. - Mikko Laitinen, Anastassia Zabrodskaja (Eds.), Dimensions of Sociolinguistic Landscapes in Europe: Materials and Methodological 
Solutions. Language Competence and Language Awareness in Europe 7. Frankfurt am Main: Peter Lang AG, 127-148.

Hämynen, Tapio 2013. Rajakarjalaisen kieliyhteisön rapautuminen ja karjalankielisten määrä Suomessa. - Pekka Suutari (Toim.), Karjala-kuvaa rakentamassa. Suomalaisen Kirjallisuuden Seuran toimituksia 1389. Helsinki: Suomalaisen Kirjallisuuden Seura, 182-213.

Ivkovic, Dejan, Heather Lotherington 2009. Multilingualism in cyberspace: Conceptualising the virtual linguistic landscape. - International Journal of Multilingualism 6, 17-36. http://dx.doi.org/10.1080/14790710802582436

Jeskanen, Matti 2005. Karjalan kieli ja karjalankieliset Suomessa. - Marjatta Palander, Anne-Maria Nupponen (Toim.), Monenlaiset karjalaiset. Suomen karjalaisten kielellinen identiteetti. Studia Carelica Humanistica 20. Joensuu: Joensuun yliopiston humanistinen tiedekunta, 215-285.

Karjalainen, Heini, Ulriikka Puura, Riho Grünthal, Svetlana Kovaleva 2013. Karelian in Russia: ELDIA Case-Specific Report. Studies in European Language Diversity 26. Mainz-Wien-Helsinki-Tartu-Mariehamn-Oulu-Maribor. http://phaidra.univie. ac.at/o:314612 (17.5.2015).

Koskinen, Kaisa 2013a. Turistina Hervannan kielimaisemassa: käännettyyden jäljillä. - Kaisa Koskinen (Toim.), Tulkattu Tampere. Tampere: Tampere University Press, 313-334.

Koskinen, Kaisa 2013b. Social media and the institutional illusions of EU communications. - International Journal of Applied Linguistics 23 (1), 80-92. http://dx.doi.org/10.1111/ijal.12018

Kunnas, Niina 2014. Suomenkarjalan kielen nykytila ja tulevaisuus. - Futura 33 (4), 18-29.

Landry, Rodrigue, Richard Y. Bourhis 1997. Linguistic landscape and ethnolinguistic vitality: An empirical study. - Journal of Language and Social Psychology 16 (1), 23-49. http://dx.doi.org/10.1177/0261927X970161002

Lemmetyinen, Anne-Mari 2015. Karjalan kielen taival ei-alueelliseksi vähemmistökieleksi Suomessa. Pro gradu -tutkielma. Itä-Suomen yliopisto.

Moshnikov, Ilia (tulossa). Čičiliusku-nukketeatteri. Nuoret luomassa uutta karjalaista identiteettiä.

Munne, Timoi 2013. Karjalan kielen voimavarat Suomessa. - Pekka Suutari (Toim.), Karjala-kuvaa rakentamassa. Suomalaisen Kirjallisuuden Seuran toimituksia 1389. Helsinki: Suomalaisen Kirjallisuuden Seura, 386-403.

Paulasto, Heli, Leena Kolehmainen, Minna Kumpulainen, Lea Meriläinen, Helka Riionheimo 2014. Interferenssi - termi tutkimussuuntausten törmäyksessä. - Virittäjä 118 (3), 408-434. 
Reh, Mechthild 2004. Multilingual writing: A reader-oriented typology - with examples from Lira Municipality (Uganda). - International Journal of the Sociology of Language 170 (1), 1-41. http://dx.doi.org/10.1515/ ijsl.2004.2004.170.1

Salmi, Leena 2014. Digitaalisen vuorovaikutuksen terminologiasta. - Marja-Liisa Helasvuo, Marjut Johansson, Sanna-Kaisa Tanskanen (Toim.), Kieli verkossa. Näkökulmia digitaaliseen vuorovaikutukseen. Suomalaisen Kirjallisuuden Seuran toimituksia 1402. Helsinki: Suomalaisen Kirjallisuuden Seura, 177-184.

Sarhimaa, Anneli 2013. Karjalan kieli Suomessa - ELDIA-projektin tuloksia. Studies in European Language Diversity 27.1. Mainz-Wien-HelsinkiTartu-Mariehamn-Oulu-Maribor. http://phaidra.univie.ac.at/o:409753 (17.5.2015).

Shohamy, Elana, Durk Gorter 2009. Introduction. - Elana Shohamy, Durk Gorter (Eds.), Linguistic Landscape. Expanding the Scenery. New York: Routledge, $1-11$.

Soria, Claudia, Joseph Mariani, Carlo Zoli 2013. Dwarfs sitting on the giants' shoulders - how LTs for regional and minority languages can benefit from piggybacking major languages. - Conference of the Foundation for Endangered Languages (FEL 2013), Ottawa, Canada, October 2013.

Torikka, Marja 2004. Karjala - kieli, murre ja paikka. Kotimaisten kielten tutkimuskeskuksen julkaisuja 129. Helsinki: Kotimaisten kielten tutkimuskeskus. http://scripta.kotus.fi/www/verkkojulkaisut/julk129/index.shtml (17.5.2016).

Toury, Gideon 1985. Aspects of translating into minority languages from the point of view of Translation Studies. - Multilingua. Journal of Cross-Cultural and Interlanguage Communication 4 (1), 3-10. http://dx.doi.org/10.1515/ mult.1985.4.1.3

Zaikov, Pëtr 2000. Glagol v karel'skom jazyke. Petrozavodsk: Izdatel'stvo Petrozavodskogo gosudarstvennogo universiteta.

\section{Muut lähteet}

SUKI = Suomalais-ugrilaiset kielet ja internet -hanke. http://suki.ling.helsinki.fi/ index.html (17.5.2016).

Всероссийская перепись населения 2010 ['Vserossijskaja perepis' naselenija = Venäjän väestönlaskenta'], viralliset tulokset. http://www.gks.ru/free_doc/ new_site/perepis2010/croc/perepis_itogi1612.htm (17.5.2015). 


\title{
Developing websites in the Karelian language as part of virtual linguistic landscape
}

\author{
ILIA MOSHNIKOV \\ University of Eastern Finland
}

Today, besides various physical linguistic landscapes, also virtual ones are being actively developed in cyberspaces such as the Internet and digital environments. Virtual linguistic landscapes have recently become a significant indicator of a level of language vitality. Indeed, minority and endangered languages are experiencing multiple opportunities to be revived and promoted.

Because of modern digitalization, the Karelian language has also become part of the Internet. Having access to the Karelian language in cyberspace enables the use this language, even when it might be difficult to find in real life. This study is focused on exploring which varieties of Karelian are used today as an optional language of communication at different websites. In addition, the study aims at investigating the contexts in which these particular websites are being developed and the initiators of this development process. The research data consists of 16 websites offering the Karelian language as a language of the virtual interface. The research material has been analyzed based on both physical and virtual linguistic landscape theories. The former type was introduced by Landry and Bourhis in 1997, and later Ivkovic and Lotherington (2009) adapted it to develop their own virtual linguistic landscape theory. Furthermore, Reh's (2004) four multilingual writing strategies, particularly duplicating, fragmentary, overlapping and complementary, have been used to analyze the interfaces and contents of the selected websites.

This study reveals that the most commonly used Karelian dialect in virtual linguistic landscapes is Livvi-Karelian; 10 out of the 16 sites use this particular variety as the language of the interface. Of the remaining websites, three use only the Karelian Proper dialect and three others offer a language choice in one of the two above-mentioned dialects. The results may primarily be explained by there being no common standard Karelian language; moreover, the Karelian language does not have an official status in any country. 
Analyzing the visibility of the Karelian language in the cyber space reveals that most websites have been developed by cultural societies, linguistic researchers, newspaper editorial teams or individuals interested in the Karelian language. Thus, this study presents an overall picture of visibility of Karelian in the Internet and suggests a few possible ways of promoting this endangered language not only in the virtual environment, but also in real life. In fact, even a minor initiative contributes to the revitalization of the Karelian language.

Keywords: revitalization; endangered language; virtual linguistic landscape; Internet; website; Karelian

\section{Ilia Moshnikov}

Itä-Suomen yliopisto, humanistinen osasto, suomen kieli ja kulttuuritieteet

PL 111

80101 Joensuu, Finland

ilia.moshnikov@uef.fi 